\title{
QUeM É O MeU PRóXIMo? SENCIÊNCIA, EMPATIA E ILIMITAÇÃo
}

Paulo Borges

(Universidade de Lisboa)

Interrogado pelos fariseus acerca de "qual o maior mandamento da Lei", Cristo respondeu "Amarás ao Senhor teu Deus de todo o teu coração, de toda a tua alma" e de todo o teu entendimento. Esse é o maior e o primeiro mandamento. $\mathrm{O}$ segundo é semelhante a esse: "Amarás o teu próximo como a ti mesmo". Desses dois mandamentos dependem toda a Lei e os Profetas" (Mateus, 22, 39). Esta resposta, que cita duas passagens do Deuteronómio $(6,5)$ e do Levítico $(19,18)$, orientou idealmente a ética do Ocidente cristão, sobrevivendo na versão laica com o segundo mandamento, que impulsionou os movimentos sociais e humanitários dos séculos XIX e XX. Notamos todavia que Cristo não se limitou ao "maior" mandamento e fez questão, não só de indicar um segundo, mas de o assumir como "semelhante" ao primeiro, reduzindo explicitamente a suposta distância entre eles. O que se confirma ao acrescentar que os "dois mandamentos" são o cerne de toda a revelação bíblica.

O amor integral a Deus e um amor ao próximo idêntico ao amor de cada um a si mesmo são para Cristo o centro da vida ética e espiritual. Os dois amores tendem aliás a convergir em Cristo num mesmo amor unitivo, se tivermos em conta a oração de Jesus ao Pai no Evangelho segundo São João: "para que sejam um, como nós somos um"; "a fim de que todos sejam um" (17, 21-23) - o que não deixa de evocar a escatológica visão de São Paulo de um Deus que virá a ser "tudo em todos" (1 Coríntios, 15, 28). A tradição judaico-cristã da qual somos herdeiros, mesmo nas versões ateia e agnóstica que sacrificam o primeiro mandamento, transmitiu-nos um entendimento pouco questionado desses dois objectos do amor como sendo, respectivamente, o Deus criador e os seres humanos, criados à sua imagem e semelhança, excluindo a restante criação, 
que existiria apenas para ser dominada pelo homem (Génesis, 1, 26) ${ }^{1}$. Não obstante interpretações mais suaves, benévolas e alternativas deste domínio $^{2}$, mais conformes aliás à clara bondade intrínseca de tudo o que Deus cria antes do homem, mundo natural e seres vivos (Génesis, 1, 1-24), e à versão de que Deus cria o homem apenas para "cultivar" e "guardar" o jardim do Éden (Génesis, 2, 15), o facto é que da narrativa bíblica se derivaram algumas das maiores justificações do antropocentrismo ocidental, que reforçou num novo sentido tendências oriundas do Neolítico, da cultura indo-europeia e das matrizes greco-romanas e hoje com a globalização capitalista, a explosão demográfica e o aumento exponencial do poder industrial e tecnológico - resulta na devastação do planeta, na desconsideração dos animais não-humanos e na manutenção de dezenas de biliões desses seres, com sensibilidade e sentimentos semelhantes aos nossos, em campos de concentração, escravatura e tortura, piores que Auschwitz ${ }^{3}$, para satisfazer a ganância das multinacionais da carne e a gula dos consumidores dos países ditos desenvolvidos.

Importa contudo questionar a interpretação dos textos, sobretudo os que se consideram sagrados e mais suscitam o apetite de instrumentalização por interesses inconfessados. Cabe questionar e reinterpretar o sentido atribuído aos dois mandamentos formulados por Cristo. Na verdade, o que é Deus? A palavra "Deus" procede da raiz indo-europeia dei, que significa "tudo o que brilha", de onde vem o português dia. Neste sentido, Deus pode interpretar-se não como um ente, distinto do homem e do mundo, mas antes como a originária irrupção da luz da consciência que permite em todos os seres a experiência sensível e inteligível do mundo. Todavia, se remontarmos à matriz hebraica, o que se designou como Deus, e precipitadamente se homologou à categoria helénica de "Ser", é antes isso que, interrogado por Moisés, se recusa nomear-se ou se nomeia como uma vida em devir aberto e indeterminado, pois interdependente do homem e do mundo com os quais se processa em relação cocriadora: ehyeh aser 'ehyeh (Exxodo, 3, 13-14), "serei o que serei; tornar-me-ei o

${ }^{1}$ Cf. a polémica tese de L. WHITE, "The historical roots of our ecological crisis", Science, 55 (10 de Março de 1967), pp.1203-1207.

${ }^{2}$ Cf. Leonardo BOFF, Ecologia: grito da terra, grito dos pobres, Rio de Janeiro, Sextante, 2004; Arne NAESS, Écologie, communauté et style de vie, tradução e prefácio de Charles Ruelle, Éditions MF, 2008, pp.267-275. Cf. as referências bibliográficas indicadas em AAVV, Éthique de l'environnement. Nature, valeur, respect, textos reunidos e traduzidos por H.-S. Afeissa, Paris, J. Vrin, 2007, pp.97-98 , notas 1 e 2 .

${ }^{3}$ Recordemos a afirmação de Theodor Adorno: "Auschwitz começa sempre que alguém olha para um matadouro e pensa: são apenas animais". 
que me tornarei" 4 . O mandamento do "amar a Deus" pode ser assim reinterpretado como o imperativo de amar integralmente essa luz da consciência elou essa vida em devir emergentes como o fundo sem fundo de tudo o que se percepciona como seres e coisas, ao ponto de, pela intensidade e plenitude desse amor, o amante e o amado se identificarem ou pelo menos se não poderem separar.

E quem é o "meu próximo"? "Próximo" vem do latim proximus, superlativo de prope ("perto, próximo"), do verbo appropiare, que significa "aproximar-se". O meu próximo será pois aquele que pertence à partida a uma mesma e determinada comunidade de funções e atributos, circunstâncias, interesses ou afectos, ou seja, aquele que pertence ao mesmo grupo familiar, profissional, social, económico, nacional, étnico, cultural, linguístico, político ou religioso? Será aquele que pertence à mesma espécie, ao mesmo planeta ou à mesma galáxia? Ou o meu próximo não está jamais definido, pois não é o que de mim está próximo por motivos acidentais, conjunturais e exteriores, mas será antes todo aquele de quem e tudo aquilo de que me aproximar, tornar e sentir próximo, mediante uma empatia e um amor que ao limite me leve a não o sentir separado de mim nem do amor que a mim mesmo dedico, como no mandamento biblico destacado por Cristo? A categoria e a experiência da proximidade não parecem pois constituir-se à margem da senciência, da potencial empatia que lhes é inerente e do grau de intensidade e extensão de ambas.

Em contexto cristão, a questão "quem é o meu próximo?" está colocada e respondida na parábola do bom samaritano. O "próximo" do homem assaltado, espancado e deixado semimorto não foi nenhum dos que passou por ele e seguiu indiferente o seu caminho, mas o que se aproximou dele, movido "de compaixão", cuidou das suas feridas e o entregou a cuidados posteriores, suportando os custos. O seu "próximo" foi o que "usou de misericórdia para com ele" e é isso que Cristo exorta a que faça quem levantou a questão (Lucas, 10, 25-37), indicando que ela só pode ser respondida com a vida e não com o intelecto. Stanislas Breton vê nesta parábola a proposta de uma "revolução tranquila", que passa pela mudança da questão: "A questão já não é: Quem é o meu próximo? mas: De quem sou eu o próximo?"5.

Nesta parábola, o que leva alguém a aproximar-se de outro e a tornar-se o seu próximo é o movimento da compaixão, do cuidado e da misericórdia suscitados pela consciência do seu sofrimento e pela sensibili-

${ }^{4} \mathrm{Cf}$. André LACOCQUE, "La révélation des révélations. Exode, 3, 14", in Paul RICOEUR/André LACOCQUE, Penser la Bible, texto de André LaCocque traduzido do inglês por Aline Patte e revisto pelo autor, Paris, Seuil, 1998, pp.326 e 329.

${ }^{5}$ Stanislas BRETON, L'avenir du christianisme, Paris, Desclée de Brouwer, 1999, p.35. 
dade a ele, que na parábola de Cristo transcendem as fronteiras étnicas e religiosas. O cuidado ético e activo expressa a compaixão e a misericórdia. A primeira, do latim compassionis, é a comunidade de sentimento ou a simpatia, que no caso da compaixão se especificou como o sentir em si a dor do outro, o participar no seu sofrimento. A segunda, do latim misericordia, significa um coração (cor, cordis, sede da inteligência, da vontade e da sensibilidade) compassivo, sensível à miseria (infelicidade, adversidade, desgraça) alheia. A compaixão e a misericórdia supõem neste caso a comum senciência ou sensibilidade do sujeito e do destinatário ou destinatários do cuidado ético.

Ainda em contexto cristão, a compaixão e a misericórdia configuram um dinamismo de autodescentramento altruísta que São Paulo considera exemplarmente no "sentimento de Cristo Jesus", exortando os cristãos a que o tenham em si e entre si. Esse "sentimento" é o de quem não se apegou ao "ser igual a Deus" e "esvaziou-se a si mesmo" (éauton ekénosen), assumindo a "condição de servo" e a "semelhança humana", pela qual se humilhou até à morte na cruz (Filipenses, 2, 5-8). Comentando esta passagem, Stanislas Breton destaca o esvaziar-se a si mesmo (ou de si mesmo) como acto radical de "perfeita [...] renúncia a tudo o que se é e a tudo o que se tem", de "absoluto desapossar de si, no seu ser e no seu ter" 6 . Esta kenose é, na leitura teológica e na tradição da filantropia ou antropotropismo do Deus bíblico ${ }^{7}$, o dinamismo fundamental da Incarnação e o modelo de toda a aproximação: é esvaziando-se de si, por amor redentor, que o Filho se torna tão próximo do homem que assume plenamente a sua forma, a sua condição, o seu sofrimento e o seu mal, pelo qual morre na cruz, tal o "Servo" de Isaías: "desprezado, não fazíamos caso nenhum dele. / E no entanto, eram as nossas enfermidades que ele levava sobre si; / as nossas dores que ele carregava" (Isaías, 53, 3-4; cf. Mateus, 8, 17). Como diz ainda São Paulo, tendo em si o mesmo autodescentramento de Cristo, os cristãos viverão "acordes no mesmo sentimento, no mesmo amor, numa só alma, num só pensamento", não "cuidando cada um só do que é seu, mas também do que é dos outros" (Filipenses, 2, 2-4).

Até aqui, todavia, estamos a falar de empatia, amor e compaixão de Deus ou do homem pelos homens, a cujo restrito número não se reduz a totalidade dos seres que podem suscitar estes sentimentos e o consequente cuidado ético. Deve-se colocar pois a questão de se não é uma limitação deste dinamismo de autodescentramento altruísta, e assim uma contradição do seu sentimento e sentido naturalmente expansivo e integrador, restringi-lo aos seres humanos e não o levar a abranger igualmente os

${ }^{6}$ Cf. Ibid., p.20.

${ }^{7}$ Cf. André Neher, L'essence du prophétisme, Calmann-Lévy, 1983, nova edição aumentada com um prefácio. 
sencientes não-humanos, como os animais, bem como os entes do mundo natural que, embora não lhes seja reconhecida uma senciência evidente e individual, possuem pelo menos existência e enquanto tal uma presença no mundo. A senciência ou sensibilidade humana não pode ou não deve estender a sua capacidade de sentir o outro como próximo a todos os seres sencientes ou sensíveis, por mínima que possa ser essa senciência ou sensibilidade, bem como a todos os seres existentes e ainda, ao limite, ao próprio mundo ou à realidade pura e simples? Com a natural diferença de que, no caso dos seres sencientes, a aproximação empática do homem a seu respeito será amorosa e jubilosa ou compassiva conforme a sua felicidade ou dor e, no caso dos existentes, do mundo e do real, a mesma aproximação empática se cumpre no simples amor jubiloso pela sua existência e presença nua, pelo puro emergir e estar aí das coisas, pelo simples haver algo, sem porquê nem para quể .

Pode-se assim questionar se o meu próximo tem de ter duas pernas e dois braços ou pode ter quatro patas, muitas ou nenhuma, caule, tronco, folhas, flores e frutos? Tem de ter cabelos e pele nua ou pode ter pêlos, penas, carapaça, escamas e casca? Tem de viver sobre a terra ou pode rastejar dentro dela e voar e brilhar nos céus? Tem de ter uma vida individual ou pode ser a própria terra, as areias, as pedras, as rochas, os minerais, as águas, os ventos, o fogo e a energia que em tudo isso circula? Tem de falar a minha linguagem ou pode miar, ladrar, zumbir, uivar, cacarejar, grunhir, mugir, relinchar, rugir, trinar, grasnar, trovejar, soprar, relampejar, chover, florir, frutificar, repousar e mover-se em silêncio? Tem de ter forma e ser visível ou pode não a ter e ser invisível? Tem de ter vida consciente e senciente? Tem de ter vida? Tem de ser algum ser ou coisa ou pode ser tudo? A empatia, o sentir o outro como o mesmo, o amor e a compaixão perante o que é animado ou a alegria amorosa perante o que simplesmente existe, têm limites? O dinamismo do descentramento altruísta tem limites? Temos limites?

A questão é que a predominante tradição ocidental, greco-romana e depois judaico-cristã, reduziu aos humanos essa aproximação compassiva do outro, que o permite considerar e sentir como "próximo". O filósofo cristão Nicolas Berdiaev notou a dificuldade do cristianismo unir o amor a Deus com o amor por todas as criaturas: "O amor pela criatura em geral, pelos animais, plantas, minerais, pela terra e pelas estrelas, não foi de todo desenvolvido na ética cristã. É um problema de ética cósmica e tem

\footnotetext{
${ }^{8}$ Cf. o sempre inspirador aforismo poético de Angelus Silesius: "Die Ros ist ohn warum; sie blühet, weil sie blühet, / Sie acht nicht ihrer selbst, fragt nicht, ob man sie siehet" ["A rosa é sem porquê; floresce porque floresce, / Não presta atenção a si mesma, não pergunta se é vista"] - Angelus SILESIUS, Cherubinischer Wandersmann, I, 289, Munique, Carl Hanser-Verlag, 1949, p.39.
} 
de ser ainda formulado"; "A consciência cristã não desenvolveu ainda uma relação moral com os animais e a natureza em geral. A sua atitude para com a natureza foi demasiado a de indiferença espiritual. E todavia o olhar nos olhos de um animal indefeso dá-nos uma experiência moral e metafísica de prodigiosa profundidade" 9 . Isto ao contrário de outras tradições, como a do "éthos hindu", que Max Scheler vê como um "éthos da simpatia" e de uma "compaixão" cósmica que "se estende a tudo o que vive", animais, plantas e, em última instância, à realidade do próprio mundo enquanto impregnado por um mesmo "sofrimento universal", o que suporia "o panvitalismo, pois não "sofre» senão o que é vivo" 10 .

Com efeito, ainda segundo Scheler, "a fusão afectiva cósmica não é possível senão na medida em que o mundo é concebido como uma «totalidade», como um organismo universal, animado por uma única vida", o que designa como a concepção organológica do mundo ${ }^{11}$. Esta concepção seria própria dos "povos não-ocidentais", tendo sido igualmente importante no Ocidente, como na doutrina platónica da "alma do mundo", até ao advento do mecanicismo da época moderna, contra o qual reagiu o romantismo. Seja como for, o cristianismo ocidental teria incorporado a ideia judaico-romana do domínio da natureza pelo homem e a sua hostilidade a qualquer forma de fusão afectiva com a natureza e os seres não-humanos, desde a tradição judaica condenada como pagã ${ }^{12}$. A grande excepção terá sido São Francisco de Assis e a sua busca de síntese da "mística amorosa acósmica" e pessoal, orientada para Deus, do amor a Jesus Cristo e da "fusão afectiva cosmovital com o ser e a vida da natureza". Com isto, segundo Scheler, "São Francisco esmaga no seu próprio núcleo a ideia judaico-romana do homem senhor da natureza, ideia que o Evangelho atenuou, sem a suprimir" 13 .

Recordemos que São Francisco, segundo Tomás de Celano, "chamava irmãs a todas as criaturas" e "sabia, graças à perspicácia do seu coração", penetrar até ao fundo mais íntimo de todas elas ${ }^{14}$. O mesmo biógrafo relata a fraternidade reverente a respeito dos animais, incluindo vermes e insectos, das pedras, das árvores, das ervas e das flores, a contemplação da Presença e da "Bondade" divina como "total em todas

${ }^{9}$ Nicolas BERDIAEV, The Destiny of Man, tradução do russo de Natalie Duddington, New York, Harper \& Brothers, 1960, pp.188 e 193.

${ }^{10} \mathrm{Cf}$. Max SCHELER, Nature et Formes de la Sympathie. Contribution à l'étude des lois de la vie affective, tradução de M. Lefebvre, Paris, Payot, 1971, pp.115-116.

${ }^{11}$ Cf. Ibid., p.119.

12 Cf. Ibid., pp. 122-123.

${ }^{13}$ Cf. Ibid., pp.127 e 131-132.

14 Tomás de CELANO, in Ibid., p.128. 
elas", afirmando que o santo vivia já no escatológico "tudo em todos"15 evocado por São Paulo (1 Coríntios, 15, 28). O célebre Cântico das Criaturas também ilustra o sentimento de fraternidade com toda a criação, louvando Deus pelo sol, lua e estrelas, vento e nuvens, água, fogo, terra e seus frutos, flores e verduras, designados como irmãos e irmãs ${ }^{16}$.

A experiência no Poverello de um afecto holístico mostra, entre muitos outros exemplos, ser possível ao homem estender a empatia aos sencientes não-humanos (animais ou também, segundo alguns, as plantas) e a todos os entes ou fenómenos naturais. Essa empatia, em relação aos primeiros, assume a forma específica da compaixão, do sentir e assumir em si o sofrimento dos outros. No que respeita aos segundos, mesmo não sendo evidente serem dotados de senciência, casos há de aberturas da consciência humana, como veremos, em que todos são percepcionados dotados de vida, a mesma vida que circula no homem e até nos objectos da cultura humana. E, mesmo quando isso não acontece, há a possibilidade da simples empatia com a presença silenciosa e anónima das coisas. Em todos estes casos, em relação aos sencientes não-humanos e aos entes e fenómenos naturais, a empatia inerente à senciência humana pode manifestar-se como compaixão, caso o mundo, por exemplo, seja experimentado como um organismo sofredor. Na sua plenitude, a empatia, compassiva ou não, parece conduzir a uma identificação, em que o sentir o outro em si culmina no senti-lo idêntico a si. Todas estas são formas de uma aproximação que, na sua maior intensidade, torna o próximo tão íntimo que o converte em idêntico, ainda que por momentos fugazes.

Schopenhauer viu o único fundamento do valor moral de um acto, pelo qual o bem de outrem é para mim um motivo ao mesmo título que o meu próprio bem, nessa identificação, pela qual cessa "toda a diferença entre eu e os outros", pelo menos até ao ponto de abolir o egoísmo que nela repousa. Embora sem me poder "meter na pele de outrem", o conhecimento dele pode levar-me ao que o filósofo designa como a "piedade", "participação totalmente imediata, sem qualquer segunda intenção", quer nas dores alheias, quer na sua cessação, ou seja, na sua felicidade. $\mathrm{Na}$ experiência desta "piedade", "único princípio real de toda a justiça espontânea e de toda a verdadeira caridade", a moral abre para a metafísica, pois "nesses momentos" apaga-se a "linha de demarcação" racional "que separa o ser do ser" e "o não-eu torna-se até certo ponto o eu"17. Como

15 Cf. Tomás de CELANO, Vida Segunda, 165, in S. Francisco de ASSIS, Escritos. Biografias. Documentos. Fontes Franciscanas, Braga, Editorial Franciscana, 1982, pp.450-451.

${ }^{16}$ Cf. Cântico das Criaturas, in Ibid., p.74.

17 Cf. SCHOPENHAUER, Le fondement de la morale, tradução de A. Burdeau, introdução, bibliografia e notas de Alain Roger, Paris, Aubier, 1978, pp.116-117. 
diz noutro passo, a respeito do outro: "cesso de o ver, como o quereria a intuição empírica, como uma coisa que me é estranha, indiferente, absolutamente distinta de mim; sofro nele, se bem que os meus nervos não estejam encerrados sob a sua pele". "Este fenómeno é", acrescenta, "um mistério", na medida em que escapa à compreensão da razão e a sua experiência não permite desvendar-lhe as causas ${ }^{18}$.

O reconhecimento da totalidade do existente como próxima e a identificação compassiva com ela avultam numa dada vertente do pensamento e da poesia portugueses, marcada por um panpsiquismo monista-panteísta que resultará na formulação por Guerra Junqueiro e Sampaio Bruno de uma "moral cósmica", que no segundo se acompanha de uma crítica radical do antropocentrismo ${ }^{19}$, a qual antecipa quase um século alguns dos argumentos anti-especistas contemporâneos.

Na raiz desta vertente destaca-se todavia a visão-experiência de Antero de Quental, sintetizada nos dois sonetos do poema "Redenção". O poeta começa por proclamar a escuta desse Logos cósmico que designa como "Verbo crepuscular e íntimo alento / Das cousas mudas", demarcando-se das tradições teoantropocêntricas que fazem do Verbo/Logos um privilégio humano e divino. Escutando as "Vozes do mar, das árvores, do vento", o que designa como "O suspiro do mundo e o seu lamento", acede a outro regime de consciência, mais profundo, subtil e compassivo, no qual reconhece como igual ao seu o "tormento" das coisas e seres da natureza. Nos antípodas da visão cartesiana de um mundo inanimado e mecanizado, onde os próprios animais seriam máquinas insensíveis $^{20}$, e nos antípodas ainda de um homem divorciado da natureza ao ponto de a sentir como uma ameaça a combater e dominar ${ }^{21}$, Antero proclama compreender a "língua estranha" em que falam as "Vozes do mar,

18 Cf. Ibid., p.141.

${ }^{19}$ Sampaio Bruno vê a "moral cósmica" expressa nos textos de Guerra Junqueiro como alternativa às falsas morais antropocêntricas, que excluem "animais" e "coisas". Afirmando como "erro antropocêntrico" "phantasiar que o universo continua subsistindo para que o desfructe o homem", proclama que "O fim do homem n'este mundo é libertar-se a si, libertando os outros sêres" - A Idéa de Deus, Porto, Livraria Chardron, 1902, pp.468-471. Sobre a importância da poesia de Guerra Junqueiro, cf. ainda O Brazil Mental, Porto, Livraria Chardron, 1898, p.290. Junqueiro escreve que "Só chegam a Deus os que levam no coração, como um filho gemendo, o Universo inteiro" - "João de Deus (biografia espiritual)", in Prosas Dispersas, Porto, Lello \& Irmão, 1978, p.84.

${ }^{20}$ René DESCARTES, Discurso do Método, in Discurso do Método e Tratado das Paixões da Alma, tradução, prefácio e notas pelo Prof. Newton de Macedo, Lisboa, Sá da Costa, 1968, pp.67-69.

21 "[...] tornando-nos assim como que senhores e possuidores da natureza" - Id., Ibid., p.73. 
da selva, da montanha", colhendo nessa escuta a revelação de que "um espírito habita a imensidade", presente na "ânsia [...] de liberdade" que pressente mover as "formas fugitivas", as existências fugazes e condicionadas de todos os seres. É nessa mesma condição que o poeta se inclui, numa exclamação de fraterna empatia: "Almas irmãs da minha, almas cativas!"22. A última expressão, "almas cativas", dará o título ao livro do menos conhecido discípulo de Antero, Roberto de Mesquita, que canta igualmente "os afectos das cousas" e a saudosa cisma que habita o "âmago" e o "íntimo de tudo", não só os entes naturais, mas também as casas e os objectos abandonados ${ }^{23}$.

A mesma experiência de animação do mundo acontece de forma mais sistemática e exacerbada em Teixeira de Pascoaes, cuja empatia com os seres e coisas conduz à transfiguração do sujeito na plena identificação com eles. Isso ocorre, por um lado, mediante o que o poeta chama o "meditar nas cousas", numa "estranha simpatia" que o dispersa "por tudo quanto existe". Nesse estado diferenciado de consciência escuta em si uma voz que proclama eu sou alguém, mas que não é apenas sua, pois "dimana de tudo" o que o "cerca". Vê então "a intimidade, o laço oculto, / Que as almas todas casa" e o "coração" se lhe converte em "pedra, nuvem, asa" 24 . Outra via, convergente, é a do descentramento e arrebatamento amoroso, pelo qual o mundo se encanta e anima e a amada fisicamente ausente se diviniza e torna omnipresente em todas as coisas, na "Natureza inteira", o que faz com que o poeta com elas se una e identifique, superando a individuação e ilimitando-se na totalidade do existente: "Vivo a vida infinita, / Eterna, esplendorosa. / Sou neblina, sou ave, /

22 Reproduzimos o primeiro soneto: "Vozes do mar, das árvores, do vento! / Quando às vezes, num sonho doloroso, / Me embala o vosso canto poderoso, / Eu julgo igual ao meu vosso tormento... // Verbo crepuscular e íntimo alento / Das cousas mudas; salmo misterioso; / Não serás tu, queixume vaporoso, / O suspiro do mundo e o seu lamento? // Um espírito habita a imensidade: / Uma ânsia cruel de liberdade / Agita e abala as formas fugitivas. / E eu compreendo a vossa língua estranha, / Vozes do mar, da selva, da montanha... / Almas irmãs da minha, almas cativas!" - Antero de QUENTAL, "Redenção", I, Sonetos, organização, introdução e notas de Nuno Júdice, Lisboa, Imprensa Nacional - Casa da Moeda, 1994, p.149. A mesma experiência de um "lamento", "desejo", "bramido" e "queixume" cósmico encontra-se em "Oceano Nox", Ibid., p.155.

${ }^{23}$ Cf. Roberto de MESQUITA, Almas Cativas e Poemas Dispersos, prefácio de Jacinto do Prado Coelho, comentário de Marcelino Lima, fixação do texto, recolha de dispersos e notas de Pedro da Silveira, Lisboa, Edições Ática, 1973, pp. 29-31, 34 e 38-40.

${ }^{24}$ Cf. Teixeira de PASCOAES, "Meditando", Sempre, in Belo. À Minha Alma. Sempre. Terra Proibida, Obra Completa, I, introdução e aparato crítico por Jacinto do Prado Coelho, s.1., Bertrand, s.d., pp.128-129. 
Estrela, Azul sem fim, / Só porque, um dia, tu, / Mulher misteriosa, / Por acaso, talvez, / Olhaste para mim" 25 .

A experiência de Pascoaes é comum a muita da poesia portuguesa emergente no início do século, que ele próprio designou como "Animismo saudosista" 26 ou "Saudosismo panteísta" 27, e que o jovem Fernando Pessoa baptizou de "transcendentalismo panteísta" 28 , vendo nela a emergência de uma nova visão filosófico-religiosa do mundo que, fundada na percepção do real como "fusão de Natureza e Alma"29, seria matriz de uma "Nova Renascença" nacional e civilizacional. A expansão cósmica do sentimento amoroso em Pascoaes não deixa de evocar a leitura de Max Scheler do "novo elemento panenteísta da identificação afectiva" de São Francisco com a "vida divina" de todas as "criaturas", o qual remontaria "ao movimento erótico provençal, inaugurado ou inspirado pelos Árabes", fortemente influente sobre Francisco antes da sua conversão, segundo a controversa tese de Paul Sabatier. Segundo Scheler, "é Eros que constitui a raiz última de toda a fusão afectiva", o qual, interpenetrado de forma única à "Agapé" no santo de Assis, teria suscitado o mais extraordinário e sublime caso "de «espiritualização da vida» e de «vivificação do Espírito»"“30.

${ }^{25}$ Cf. Id., "Elegia do Amor", Vida Etérea, in À Ventura. Jesus e Pã. Para a Luz. Vida Etérea, Obra Completa, II, introdução e aparato crítico por Jacinto do Prado Coelho, s.1., Bertrand, s.d, p.182. Vejam-se outras passagens: "Tudo, em volta de nós, / Tinha um aspecto de alma. Tudo era sentimento, / Amor e piedade. / A folha que tombava / Era alma que subia... / E, sob os nossos pés, / A terra era saudade, / A pedra comoção / E o pó melancolia" - Ibid., p.174; "tudo de ti me fala, / Ó meu longínquo amor: / As árvores, a névoa, / Os rouxinóis e o mar" - Ibid., p.178; "O meu amor por ti, / Meu bem, minha saudade, / Ampliou-se até Deus, / Os astros alcançou. / Beijo o rochedo e a flor, / A noite e a claridade. / São estes, sobre o mundo, / Os beijos que te dou" - Ibid., pp.178-179; "Descubro-te, mulher, / Da natureza inteira" - Ibid., p.180; "Um vago e etéreo laço / Prende-me ao teu imenso / E livre coração, / Que abrange o mundo inteiro / E ocupa todo o espaço, / E que vai povoar / A minha solidão. / Por isso, eu vivo sempre, / Em doce companhia" Ibid., pp.181-182.

${ }^{26}$ Cf. Teixeira de PASCOAES, O génio português na sua expressão filosófica, poética e religiosa (1913), in A Saudade e o Saudosismo (dispersos e opúsculos), compilação, introdução, fixação do texto e notas de Pinharanda Gomes, Lisboa, Assírio \& Alvim, 1988, p.77.

27 Cf. Ibid., p.82.

${ }^{28}$ Cf. Fernando PESSOA, A nova poesia portuguesa no seu aspecto psicológico, Obras, II, organização, introduções e notas de António Quadros, Porto, Lello \& Irmão - Editores, 1986, p.1189.

${ }^{29}$ Cf. Id., Uma réplica (Ao Dr. Adolfo Coelho), Ibid., p.1202.

${ }^{30}$ Cf. Max SCHELER, Nature et Formes de la Sympathie. Contribution à l'étude 
Decerto que a experiência místico-poética de uma divina animação do mundo pode ser sempre denunciada como lirismo romântico próprio de "poetas místicos" que seriam "filósofos doentes", sendo já os filósofos "homens doidos", como o diz Alberto Caeiro"31. Todavia, experiências espontâneas de alteração e expansão da consciência, sem qualquer intenção, preparação ou indução, verificadas em pessoas sem conhecimentos e interesses poéticos, religiosos ou espirituais, parecem confirmar as grandes intuições místicas, filosóficas, estéticas ou poéticas da humanidade acerca de uma comunidade vital de todo o existente, onde tudo o que na vida suposta normal se apreende como indiferente, distinto e distante subitamente aparece como tremendamente significante, próximo e íntimo. Veja-se, entre muitos exemplos, o relato do ocorrido à senhora Margaret Prescott Montague, em 1915:

"[...] neste cenário de todos os dias, e de um modo inteiramente inesperado (pois jamais havia sonhado com tal coisa), os meus olhos foram abertos e, pela primeira vez em toda a minha vida, tive um vislumbre da beleza extática da realidade... [...] Não vi nenhuma coisa nova, mas vi todas as coisas habituais numa miraculosa luz nova - no que acredito ser a sua verdadeira luz. Vi pela primeira vez quão selvaticamente bela e jubilosa, para além de quaisquer palavras minhas para o descrever, é a totalidade da vida. Cada ser humano atravessando aquela varanda, cada pardal que voava, cada ramo oscilando ao vento, estava integrado e era parte do inteiro e louco êxtase de encanto, alegria, significância e embriaguez da vida. Não que por uns poucos e excitados momentos eu imaginasse toda a existência como bela, mas, antes, a minha visão interna foi desobstruída para a verdade, de modo que $v i$ o real encanto que está sempre aí, mas que tão raramente percepcionamos, e soube que todo o homem, mulher, ave ou árvore, toda a coisa viva diante de mim, era extravagantemente bela e extravagantemente importante. E, ao contemplar, o meu coração fundiu-se e abandonou-me num arrebatamento de amor e deleite. [...] Uma vez, no meio de todos os cinzentos dias da minha vida, vi o coração da realidade; fui testemunha da verdade" 32 .

des lois de la vie affective, pp.133-135. Cf. Paul Sabatier, Vie de saint François d'Assise, Paris, Fischbacher, 1894.

31 Cf. Alberto CAEIRO, "O Guardador de Rebanhos", in Fernando PESSOA, Obras, I, introduções, organização, biobibliografia e notas de António Quadros e Dalila Pereira da Costa, Porto, Lello \& Irmão - Editores, 1986, p.764.

32 Cf. Margaret Prescott MONTAGUE, Twenty Minutes of Reality. An experience with some illuminating letters concerning it, New York, E. P. Dutton \& Company, s. d., pp.7-11. Sobre esta experiência, cf. W. T. STACE, Mysticism and 
Nesta experiência o centro não está, como em Schopenhauer ou Antero de Quental, na empatia compassiva com a dor do outro, mas antes na empatia e abertura estética ou, melhor, estésica, da consciência, numa percepção da "totalidade da vida" em que se indissociam beleza, verdade, realidade e jubilosa plenitude, sem que nesta totalidade se diluam os seres e fenómenos individuais, que pelo contrário nela manifestam todo o destaque e pregnância que lhes são velados pelo embotamento da percepção dita normal, a qual, ao captar apenas o pouco no qual está utilitariamente interessada em função do agir, e de um modo conforme a esse interesse, deixa na penumbra toda a restante e imensa multiplicidade do real, como o destacou Bergson ${ }^{33}$. Note-se ainda, na experiência relatada, que a vívida evidência de cada ente singular no seio da mesma totalidade vital é comum a todos, sendo a mesma em cada "ser humano", "pardal, "ramo", "árvore" ou "coisa viva", como igualmente intensas e absolutamente significantes expressões do real, livres de qualquer juízo de valor condicionado por interesses subjectivos e assim alheias a qualquer hierarquia onto-axiológica construída a partir de uma perspectiva, como habitualmente a humana, divorciada da unidade orgânica do todo. Por outro lado, esta contemplação da eminente e irredutível importância, significância e beleza de todas as coisas, como idênticas fulgurações da totalidade da vida e do real, não deixa de ser extática para o sujeito da experiência, que nela se funde e absorve amorosa e fruitivamente, não podendo permanecer a seu lado como um observador frio, distanciado e invulnerável. $\mathrm{O}$ sujeito é absorvido na experiência, que deixa de ser a de um objecto, sendo nesse arrebatador descentramento que acede ao "coração da realidade". A plenitude da empatia estésica, onde se dilui a dualidade da percepção convencional, é simultaneamente uma experiência de plena realização, que entremostra a irrealidade da versão oficial e supostamente normal do mundo, a esta luz denunciada como uma mera construção de percepções condicionadas pelos interesses e hábitos social e histórico-culturalmente dominantes.

Admitimos que a experiência relatada por Margaret Prescott Montague integre a família das mais fundas e originárias experiências, porven-

Philosophy, Londres, The MacMillan Press, 1972, pp.83-84; Michel HULIN, La Mystique Sauvage. Aux antipodes de l'esprit, Paris, PUF, 1993, p.37.

33 “Vivre consiste à agir. Vivre, c'est n'accepter des objets que l'impression utile pour y répondre par des réactions appropriées: les autres impressions doivent s'obscurcir ou ne nous arriver que confusément. [...] Mes sens et ma conscience ne me livrent donc de la réalité qu'une simplification pratique" - Henri BERGSON, Le Rire. Essai sur la signification du comique, in Oeuvres, textos anotados por André Robinet, introdução por Henri Gouhier, Paris, PUF, 1991, p.459. 
tura não apenas humanas, pois enquanto pré-reflexivas podem ser comuns a todas as formas de vida consenciente, que de algum modo, pelo menos nos intervalos da luta pela sobrevivência, provavelmente participam nessa sentida e pré-conceptual plenitude, bondade e graça da própria vida. Sem aqui poder aprofundar esta questão, nisto nos demarcamos dos vários dolorismos ontológicos que predominam na leitura de algumas tradições orientais, em particular na do budismo, bem como em certas versões do cristianismo, nalgumas visões gnósticas da existência, em Schopenhauer e nos pensadores portugueses atrás referidos, com destaque para Sampaio Bruno, pese a sua ambiguidade. Nisto nos demarcamos também de pensadores que, focados na experiência individual da senciência humana e animal, reduzem a ética à gestão da busca do bem-estar e do evitar o sofrimento, sem reconhecer o seu fundamento no êthos não-dual da empatia jubilosa com a vida na unitotalidade das suas manifestações.

Seja como for, enquanto a experiência da vida for a de uma trágica ou tragicómica sucessão de experiências felizes e infelizes, alegres e dolorosas, por organismos psicofísicos dotados de uma senciência não educada e treinada para a superação dessas percepções opostas na estabilidade e plenitude de uma consciência não-dual (conforme o homem pode fazer pelo milenar treino meditativo ${ }^{34}$ ), a empatia oscilará sempre entre o regozijo e a compaixão pelos seres sencientes e pelo mundo enquanto se lhe reconhecer vida, num processo que pode conduzir à identificação com o outro, em todas as suas formas, e assim a uma profunda autorealização de si por expansão ou ilimitação ontológica. É uma das intuições da ecologia profunda, segundo Arne Naess, que na sua maturidade os humanos "terão a experiência da alegria e do sofrimento quando outras formas de vida têm a experiência da alegria ou do sofrimento. Não só nos sentiremos tristes quando o nosso irmão, ou um cão, ou um gato, se sentem tristes, mas sentiremos dor quando seres vivos, incluindo paisagens, são destruídos" 35 . Foi a experiência do próprio autor, assim narrada:

"O meu exemplo-padrão envolve um ser não-humano que encontrei há quarenta anos. Estava a contemplar através de um velho microscópio o dramático encontro de duas gotas de diferentes químicos.

${ }^{34}$ Cf. B. Alan WALLACE, Mind in the Balance. Meditation in Science, Buddhism and Christianity, Nova Iorque, Columbia University Press, 2009; Paulo BORGES, "A meditação entre Oriente e Ocidente ou a actual e urgente redescoberta de um antigo paradigma", Biosofia, n 40 (Lisboa, Inverno 2011/12), pp.9-18.

35 Arne NAESS, in Bill DEVALL/George SESSIONS, Ecologia Profunda. Dar prioridade à natureza na nossa vida, Águas Santas, Edições Sempre-em-Pé, 2004, p.96. 
Nesse momento, uma pulga saltou de um lemingue que estava a deambular pela mesa e aterrou no meio dos ácidos químicos. Salvá-la era impossível. Levou muitos minutos para que a pulga morresse. Os seus movimentos eram horrivelmente expressivos. Naturalmente, o que senti foi uma dolorosa sensação de compaixão e empatia, mas a empatia não era elementar; era antes um processo de identificação: «eu vi-me a mim mesmo na pulga»“36.

A consciência e a senciência humana, a consenciência humana, configura a emergência de uma possibilidade de empatia alargada a todos os seres sencientes, à vida e à realidade na sua unitotalidade, singularidade que, em vez de legitimar o seu domínio antropocêntrico, responsabiliza o homem por um "cuidado universal" 37 onde a ética, mais do que um dever-ser moral ou religioso, se enraíze num originário habitar (cf. o grego êthos, lugar de habitação ou morada) empaticamente o mundo ${ }^{38}$. Como sustenta Naess, nessa identificação solidária com os seres e a vida, mediante o reconhecimento e interiorização do seu comum interesse ou impulso para a preservação e plena expansão de si $^{39}$, são os próprios egos fragmentários e limitados que se desenvolvem proporcionalmente à extensão e grandeza da totalidade com que se identificam, ao ponto do "ego pessoal" e do "organismo" já não serem "limites adequados ao seu próprio si-mesmo", que se experimenta como "parte autêntica de toda a vida", reconhecendo a igualdade de todos os viventes como fins em si mesmos dotados de valor intrínseco ${ }^{40}$. Neste patamar da consenciência, o bem que se busca como "próprio" é na verdade o bem de cada um e de todos, pois "a distinção próprio/impróprio subsiste apenas na gramática, mas não nos sentimentos" ${ }^{41}$.

36 Arne NAESS, "Self-Realization: An Ecological Approach to Being in the World", in AAVV, Deep Ecology for the 21st Century, editado por George Sessions, Boston, Shambhala, 1986, citado em Andrew BRENNAN / Y. S. LO, Understanding Environmental Philosophy, Durham, Acumen Publishing, 2010, p.103.

${ }^{37}$ Cf. Arne NAESS, Écologie, Communauté et Style de Vie, pp.250-251.

${ }^{38}$ Cf. Maria José VARANDAS, Ambiente. Uma questão de ética, Lisboa, Esfera do Caos, 2009.

${ }^{39}$ Cf. Arne NAESS, Écologie, Communauté et Style de Vie, p. 253.

40 Cf. Ibid., p. 255.

${ }^{41}$ Cf. Ibid., pp.256-257. "Pois Naess sugere que podemos escolher cultivar um mais amplo si-mesmo pela nossa própria identificação com a natureza e as coisas naturais, mediante a expansão do nosso círculo de tal identificação de modos que nos nutram e enriqueçam. Desta forma, o si-mesmo ecológico não é apenas uma espécie de coisa maleável, sendo também construído pelas identificações que escolhe fazer. Tal como na noção de iluminação de Gandhi, derivada do pensa- 
Escreveu Antero de Quental, antecipando um século uma ética não-antropocêntrica: "Como não há-de então o justo dar-se aos outros, dar-se a todos os seres, se com cada acto de dedicação conquista e firma a própria beatitude? Libertando-os, liberta-se: aperfeiçoando-os, aperfeiçoa-se: beatificando-os, beatifica-se. Para conseguir o próprio bem, tem de se fazer como o instrumento do bem universal. E nem verdadeiramente para conseguir o próprio bem: porque, despojado de personalidade e egoísmo, morto para o eu individual, o bem atrai-o em si ou fora de si, indiferentemente, e tende a realizá-lo seja onde for, seja sob que forma for, simplesmente porque é o bem".

Cremos que a ética místico-metafísica de Antero vai mais longe que a ecosofia de Naess em termos de realização ontológica, pois como corolário da realização ética o justo deixa de constituir "uma individualidade particular, circunscrita no tempo e no espaço, condicionada pelo temperamento, pela raça, pela nação, pelo período histórico, pela educação, por mil circunstâncias fortuitas", para se converter na mera forma exterior de um "princípio universal, impessoal, absoluto", que evolui na totalidade do processo cósmico e em cada radical renúncia individual ao egoísmo se autorealiza e liberta plenamente, numa superação da individuação que é paradoxalmente a sua realização plena numa "santidade" cósmica ${ }^{42}$.

Após este percurso, consideramos possível reinterpretar os dois mandamentos formulados por Cristo num sentido que supere o teoantropocentrismo tradicional, assumindo ao mesmo tempo a sua convergência ou mesmo inseparabilidade. Na verdade, amar a Deus e ao próximo como a si mesmo, à luz do próprio sentido originário destas palavras, pode não ser outra coisa senão amar incondicionalmente esse fundo em devir da consciência e da vida, bem como todas as formas em que se manifesta e que igualmente o expressam, sejam sencientes, viventes ou existentes, sem preferências nem exclusões, mediante uma empatia que experimente todas como tão próximas ou íntimas que revele a sua inseparável integra-

mento hindu, na qual o ser iluminado "se vê a si mesmo em toda a parte", a ecologia profunda instiga-nos a encontrar realização mediante a identificação com a natureza. Em vez de avançar com uma ética que nos mande fazer o nosso dever, ou controlar os nossos desejos e apetites, Naess esperava que a sua forma de auto-realização nos iria encorajar a procurar o nosso próprio bem, como a sua directiva primária. Uma tal ética salvará o mundo, espera ele, mas não por via de fazer da regra "salva o mundo" a nossa primeira norma de conduta" - Andrew BRENNAN / Y. S. LO, Understanding Environmental Philosophy, Durham, Acumen Publishing, 2010, pp.103-104.

42 Antero de QUENTAL, Tendências Gerais da Filosofia na Segunda Metade do Século XIX, in Filosofia, organização, introdução e notas de Joel Serrão, Ponta Delgada / Lisboa, Universidade dos Açores / Editorial Comunicação, 1991, pp.166-167. 
ção numa mesma comunidade cosmovital. Por essa empatia, jubilosa ou compassiva, e numa releitura ainda da experiência cristã, cada sujeito se auto-esvazia e descentra para a totalidade, vivendo a mesma experiência da kenose de Cristo, mas agora aberta à vida e a todos os seres e não restrita à humanidade. É esse auto-esvaziamento desegoízador que, até um certo ponto ainda como em Cristo, segundo São Paulo, conduz não à mera aniquilação do sujeito, mas à sua transfigurada exaltação e ilimitação, embora aqui não no "Pai" (Filipenses, 2, 9-11), acima de toda a criação, mas na plenitude da consciência ou vida em devir imanente à comunidade cósmica, permitindo-lhe viver desde já, e de forma mais ampla que na escatologia de São Paulo ${ }^{43}$, o ser tudo em todos e todas as coisas.

\section{ABSTRACT}

This paper aims to rethink the traditional understanding of the two commandments formulated by Christ - to love God and our neighbour as ourselves -, by rethinking the category of neighbour, not just as those who belongs to the human species, but as all those to whom we can feel close, depending on the degree of empathy concerning not just sentient beings, but even all forms of life and existence. Rethinking also God not as the supreme being, but (according to the etymology) as the light of the full awareness of life itself, we propose that to live wholeheartedly the two commandments implies to die and resurrect as being everything in all and all things.

${ }^{43}$ Cf. São PAULO, 1 Coríntios, 15, 28. 